\title{
FAKTOR-FAKTOR YANG MEMPENGARUHI KEPUTUSAN WISATAWAN DALAM MEMBELI PAKET WISATA DI PT. BALI SUCI TOUR AND TRAVEL
}

\author{
Marulina Sitohang \\ I Wayan Suardana \\ I Putu Sudana \\ Email : lina.sitohang@ymail.com \\ PS. S1 Industri Perjalanan Wisata \\ Fakultas Pariwisata UNUD
}

\begin{abstract}
ABSTRAK
Penelitian ini bertujuan untuk mengetahui: (1) faktor yang mempengaruhi keputusan wisatawan dalam membeli paket wisata; (2) faktor yang mempunyai pengaruh paling dominan dalam keputusan pembelian paket wisata. Populasi dalam penelitian ini meliputi seluruh wisatawan yang membeli paket wisata di PT. Bali Suci Tour \& Travel. Penentuan sampel dalam penelitian ini menggunakan metode purposive sampling dan yang menjadi kriteria adalah wisatawan yang pernah membeli paket wisata di PT. Bali Suci Tour and Travel dengan jumlah sampel sebanyak 200 responden. Teknik pengumpulan data menggunakan kuisioner dengan teknik analisis data analisis faktor.

Hasil penelitian menunjukkan bahwa dari 20 variabel dapat direduksi menjadi 18 variabel yang tersebar dalam 5 (lima) faktor. Terdapat 2 (dua) variabel dikeluarkan dari model karena tidak memenuhi kriteria MSA > 0,5 yaitu variabel product quality (X1.7) dan variabel product offering (X1.13). Dari uji analisis faktor diperoleh hasil bahwa dari 18 variabel yang ditahan di dalam model dan mengelompokkan ke dalam 5 faktor merupakan faktor-faktor yang mempengaruhi keputusan wisatwan dalam membeli produk paket wisata. Faktor-faktor tersebut adalah faktor produk dengan eigenvalue 5,871, faktor pribadi dengan eigenvalue 3,452, faktor psikologi dengan eigenvalue 3,144, faktor sosial dengan eigenvalue 2,197, dan faktor harga dengan eigenvalue 1,151. Dari hasil analisis faktor juga diketahui bahwa faktor yang memengaruhi keputusan wisatawan dalam membeli paket wisata paling dominan adalah faktor produk karena memiliki loading factor tertinggi dari keseluruhan faktor yang sudah terbentuk. Adapun variabel yang termasuk dalam faktor produk adalah packaging, guarantee, perceived fit, dan kualitas fasilitas.
\end{abstract}

\section{Kata Kunci: Keputusan Pembelian, Analisis Faktor.}

\section{PENDAHULUAN}

Pada dasarnya kegiatan perjalanan telah lama dilakukan oleh manusia. Di dalam hidupnya manusia selalu bergerak, berpindah dari satu tempat ke tempat lainnya, dan ini merupakan ciri pola kehidupan manusia. Sama halnya dengan perjalanan wisata yang juga sudah menjadi suatu pola konsumsi tersendiri yang bersaing dengan barang-barang mewah lainnya (Yoeti, 2008). Dalam kepariwisataan
Indonesia, Bali merupakan salah satu pulau yang sangat diunggulkan, karena memiliki keanegaragaman budaya, adat yang kental, dan juga kekayaan alam yang sangat menarik minat wisatawan untuk datang dan melakukan perjalanan wisata. Sebagai daerah tujuan wisata dengan keunggulan dan keunikan objek dan atraksi wisata yang dimiliki, Bali telah didukung oleh sarana dan prasarana pariwisata yang cukup memadai seperti jalan menuju daya tarik, sarana 
akomodai seperti hotel berbintang dan non bintang, villa, restoran, sarana transportasi serta dukungan Pemerintah dan masyarakat Bali dalam menjaga keamanan.

Dalam dunia pariwisata, Biro Perjalanan Wisata (BPW) merupakan salah satu pokok yang dapat dimanfaatkan oleh wisatawan dalam memudahkan melakukan perjalanan wisata. Menurut Pendit (dalam Yoeti, 2003) pengertian Biro Perjalan Wisata adalah perusahaan yang mempunyai tujuan untuk menyiapkan suatu perjalanan (tour) bagi seseorang yang merencanakan untuk mengadakan perjalanan. Sesuai dengan isi pasal 4 Bab II Surat Keputusan Dirjen Pariwisata No.Kep.16/U/II/88 tahun 1988, adapun ruang lingkup usaha sebuah Biro Perjalanan Wisata antara lain (1) membuat, menjual dan mnyelenggarakan paket wisata, (2) mengurus dan melyani kebutuhan jasa angkutan bagi perorangan dan atau kelompok orang yang diurusnya, (3) melayani pemesanan akomodasi, restoran, dan sarana wisata lainnya, (4) mengurus dokumen perjalanan, menyelenggarakan panduan perjalanan wisata, dan (6) melayani penyelenggaraan konvensi.

Salah satu BPW yang ada di Bali adalah Bali Suci Tour \& Travel, yang telah berdiri sejak tahun 1999 hingga sekarang. Produk yang ditawarkan oleh Bali Suci Tour \& Travel beragam, mulai dari tiket pesawat, paket wisata seperti paket wisata inbound, outbound, honeymoon, watersport, dan jenis paket wisata kombinasi lainnya. Jumlah pengguna paket wisata di Bali Suci Tour \& Travel juga mengalami fluktuasi sejak tahun 2010 hingga tahun 2014. Hal ini dipengaruhi oleh kondisi ekonomi, adanya inovasi terhadap produk, juga karena pengaruh perkembangan teknologi yang cenderung memudahkan akses informasi terutama melalui media eketronik seperti internet bagi wisatawan untuk merencanakan perjalanan secara mandiri. Namun ditengahtengah perkembangan ini, tentunya masih banyak wisatawan yang merencanakan kegiatan perjalanan wisata bahkan memutusakan untuk membeli paket wisata melalui biro perjalanan wisata. Hal ini yang menarik perhatian penulis dalam melakukan penelitian mengenai faktorfaktor yang mempengaruhi keputusan wisatawan dalam membeli paket wisata di Bali Suci Tour \& Travel. Berdasarkan latar belakang tersebut, tujuan dari penelitian ini adalah : untuk mengetahui faktor-faktor apakah yang mempengaruhi keputusan wisatawan dalam membeli paket wisata di PT. Bali Suci Tour \& Travel dan untuk mengetahui faktor-faktor mana yang dominan mempengaruhi keputusan wisatawan dalam membeli paket wisata di PT. Bali Suci Tour \& Travel.

\section{METODELOGI PENELITIAN}

Penelitian ini dilakukan di PT. Bali Suci Tour \& Travel yang berlokasi di Jalan Tukad Batanghari No.68 Panjer, Denpasar, Bali. Jenis penelitian ini aalah deskriptif kuantitatif. Populasi yang dijadikan sampel dalam penelitian ini adalah wisatawan nusantara maupun mancanegara yang membeli paket wisata di PT. Bali Suci Tour \& Travel. Teknik pengumpulan sampel yang digunakan dalam penelitian ini adalah purposive sampling yakni teknik penentuan sampel dengan pertimbangan tertentu (Sugiyono, 2011). Sedangkan untuk menentukan jumlah sampel yang digunakan dalam penelitian ini menggunakan model yang mengalikan 5 sampai 10 dengan jumlah pertanyaan atau indikator dalam kuesioner. Adapun jumlah indikator dalam penelitian ini adalah sebanyak 20 indikator, kemudian dikali 10 maka jumlah wisatawan yang dijadikan sampel adalah sebanyak 200 orang.

\section{Operasional Penelitian dan Deskripsi Variabel}

Setelah melakukan telaah pustaka untuk mengetahui indikator yang mempengaruhi keputusan konsumen dalam membeli paket wisata, maka yang menjadi variabel bebas (X) dalam penelitian ini adalah Keputusan Pembelian dengan indikator sebanyak 20 yakni family member (X1.1), pendapatan (X1.2), education level (X1.3), group factor (X1.4), kualitas fasilitas (X1.5), behavior (X1.6), product quality (X1.7), motivasi (X1.8), pembelajaran (X1.9), usia (X1.10), persepsi (X1.11), sosial (X1.12), product offering (X1.13), guarantee (X1.14), resiko (X1.15), price offering (X1.16), price awareness (X1.17), perceive fit (X1.18), packaging (X1.19), dan life style (X1.20). 


\section{Prosedur Pengumpulan Data}

Sumber data dalam penelitian ini diperoleh dari data primer dan data sekunder. Data primer merupakan data yang didapat langsung melalui proses penelitian sebagai data primer, diantaranya bersumber dari hasil angket wisatawan, karyawan, dan data yang diperoleh dari berbagai pihak terkait. Sedangkan data sekunder merupakan data yang bersumber secara tidak langsung dari perusahaan terkait, namun dari berbagai buku atau literatur yang relevan dan memiliki hubungan dengan penelitian hasil laporan, serta data resmi dari instansi terkait. Prosedur pengumpulan data dalam penelitian ini terdiri dari observasi, studi kepustakaan, dan kuesioner. Pengukuran variabel dalam penelitian ini dilalukan dengan metode skoring. Pemberian skor dilakukan menggunakan skala likert. Skala likert merupakan pengukuran dengan memberikan bilangan bulat $1,2,3,4,5,6$, dan 7 pada setiap kemungkinan jawaban yang diberikan. Untuk skor 1 menyatakan sangat tidak setuju, 2 menyatakan tidak setuju, 3 menyatakan agak tidak setuju, 4 menyatakan netral, 5 menyatakan agak setuju, 6 menyatakan setuju dan 7 menyatakan sangat setuju.

\section{Teknik Analisis Data}

Teknik analisis data yang digunakan dalam penelitaian ini terdiri dari beberapa tahapan seperti uji validitas dan reliabilitas serta analisis faktor.

\section{HASIL DAN PEMBAHASAN \\ Karakteristik Responden}

Penelitian ini menggunakan 200 sampel yang merupakan wisatawan pengguna paket wisata di PT.Bali Suci Tour \& Travel. Berdasarkan kuesioner yang disebar, maka diperoleh data bahwa wisatawan pengguna paket wisata di PT.Bali Suci Tour \& Travel didominasi oleh wanita sebanyak 107 orang serta dengan rentang usia 21-30 tahun sebanyak 118 orang. Dilihat dari sisi pekerjaan wisatawan, wisatawan dengan pekerjaan sebagai pegawai swasta mendominasi yakni sebanyak 59 orang.

\section{Analisis Faktor}

Selanjutnya, data yang diperoleh dari kuesioner yang telah disebarkan yakni sebanyak 200 sampel terkait faktor-faktor yang mempengaruhi keputusan wisatawan dalam membeli paket wisata, dianalisis dengan analisis faktor menggunakan SPSS for Windows 16.0.0. Adapun tahapan yang dilakukan dalam analisis faktor adalah sebagai berikut :

1. Merumuskan Masalah

Melalui analisis faktor, maka dapat diketahui faktor-faktor yang mempengaruhi keputusan wisatawan dalam membeli paket wisata di PT. Bali Suci Tour \& Travel yang diidentifikasikan dari 20 variabel penentu keputusan pembelian. Sampel responden yang berjumlah 200 orang yang dipilih dari para wisatawan pengguna paket wisata PT. Bali Suci Tour \& Travel.

2. Membuat Matriks Korelasi

Pada tahap ini ditemukan bahwa nilai KMO mencapai 0,774 dengan signifikasi 0,000 yang berarti analisis ini dapat dilanjutkan ke tahap berikutnya yaitu tahap uji MSA (Measuring of Sampling Adequacy). Pada tahap ini akan ditampilkan 20 indaktor bersama nilai MSA, dan indikator dengan nilai MSA dibawah 0,5 harus dikeluarkan dari analisis, hal ini terus dilakuakan berulang kali hingga tidak ada lagi indikator dengan nilai dibawah 0,5 . Dalam hal ini terdapat 2 indikator yang memiliki nilai indikator di bawah 0,5 yakni indikator product quality (X1.7) dan indikator product offering (X1.13), sehingga kedua indikator ini harus dikeluarkan/dielimnasi dan dilakukan proses uju interpedensi tahap kedua. Pada tahap ini, dilakukan pengujian terhadap 18 indikator tersisa dengan nilai KMO 0,782 dengan signifikansi 0.000 berarti analisis dapat dilanjutkan kembali. Pada nilai MSA, dapat dilihat bahwa semua nilai yang dimiliki masing-masing indikator sudah memenuhi syarat yakni $>0,5$, sehingga dapat dilanjutkan pada tahap ekstraksi faktor.

3. Ekstraksi Faktor

Ektraksi faktor digunakan untuk mereduksi data dari beberapa indikator untuk menghasilkan faktor ang lebih sedikit yang mampu menjelaskan korelasi antara indikator yang diobservasi. Dalam tahap ini, nilai eigenvalue $\geq 1$ merupakan nilai yang dipilih. Dari hasil analisis maka dari 18 indikator terdapat lima (5) faktor yang 
memiliki eigenvalue $\geq 1$, yaitu 5,$871 ; 3,452$; 3,144; 2,197; dan 1,151 dengan cumulative eigenvalue sebesar $87,856 \%$.

4. Rotasi Faktor

Berdasarkan hasil analisis rotasi, maka dapat dijelaskan bahwa terdapat lima (5) faktor yang sudah terbentuk. Faktor 1 terdiri dari empat (4) vairabel berkorelasi yakni packaging, guarantee, perceive fit, dan kualitas fasilitas. Faktor 2 terdiri dari empat (4) variabel berkorelasi yakni usia, income, education level, dan life style. Faktor 3 terdiri dari empat (4) variabel berkorelasi yakni persepsi, behavior, motivasi, dan pembelajaran. Faktor 4 terdiri dari tiga (3) variabel berkorelasi yakni sosial, family member, dan group factor. Dan yang terakhir faktor 5 yang terdiri dari tiga (3) variabel yang berkorelasi yakni price offering, resiko, dan price awareness.
5. Interpretasi Faktor

Pada penelitian ini, ada beberapa variabel yang dikeluarkan atau dieliminasi karena tidak melewati nilai loading factor $>0,5$ yakni Product Quality (X1.7) dan Product Offering (X1.13). Berdasarkan batasan tersebut, maka dari 20 variabel yang dianalisis lewat MSA (Meaure of Sampling Adequacy) yang diatas 0,5 nampaknya dari seluruh total variabel awal (20 variabel) yang dianalisis lebih lanjut hanya terdapat 18 variabel yang memenuhi loading factor $>$ 0,5 yang tergabung dalam 5 (lima) faktor. Faktor yang merupakan gabungan dari satu variabel harus diberi nama. Pemberian nama harus mengacu pada variabel-variabel yang membentuk faktor yang bersangkutan. Berikut penamaan faktor sesuai dengan variabel yang membentuk :

\begin{tabular}{|c|c|c|c|c|}
\hline No & $\begin{array}{l}\text { Nama } \\
\text { Faktor }\end{array}$ & Nama Variabel & $\begin{array}{c}\text { Loading } \\
\text { Factor }\end{array}$ & $\begin{array}{c}\% \\
\text { Variance }\end{array}$ \\
\hline \multirow{4}{*}{1.} & \multirow{4}{*}{$\begin{array}{l}\text { Faktor } \\
\text { Produk }\end{array}$} & Packaging (X1.19) & 0,929 & \multirow{4}{*}{32,618} \\
\hline & & Guarantee (X1.14) & 0,875 & \\
\hline & & Perceived Fit (X1.18) & 0,873 & \\
\hline & & Kualitas Fasilitas (X1.5) & 0,837 & \\
\hline \multirow{4}{*}{2.} & \multirow{4}{*}{$\begin{array}{l}\text { Faktor } \\
\text { Pribadi }\end{array}$} & Usia (X1.10) & 0,972 & \multirow{4}{*}{19,176} \\
\hline & & Income (X1.2) & 0,934 & \\
\hline & & Education Level (X1.3) & 0,898 & \\
\hline & & Life Style (X1.20) & 0,891 & \\
\hline \multirow{4}{*}{3.} & \multirow{4}{*}{$\begin{array}{l}\text { Faktor } \\
\text { Psikologi }\end{array}$} & Persepsi (X1.11) & 0,945 & \multirow{4}{*}{17,466} \\
\hline & & Behaviour (X1.6) & 0,936 & \\
\hline & & Motivasi (X1.8) & 0,922 & \\
\hline & & Pembelajaran (X1.9) & 0,765 & \\
\hline \multirow{3}{*}{4.} & \multirow{3}{*}{$\begin{array}{l}\text { Faktor } \\
\text { Sosial }\end{array}$} & Sosial (X1.12) & 0,966 & \multirow{3}{*}{12,204} \\
\hline & & Family Member (X1.1) & 0,951 & \\
\hline & & Group Factor (X1.4) & 0,946 & \\
\hline
\end{tabular}




\begin{tabular}{lllc}
\hline & \multicolumn{2}{l}{ Price Offering (X1.16) } & 0,897 \\
5. & Faktor & \multirow{2}{*}{ Resiko (X1.15) } & 0,876 \\
\cline { 3 - 3 } & Harga & Resice Awareness (X1.17) & 0,868
\end{tabular}

a. Faktor Produk, dengan persentasi varian sebesar 32,618\% terdiri dari packaging, guarantee, perceive fit, dan kualitas fasilitas.

b. Faktor Pribadi, dengan persentasi varian sebesar 19,176\%yang terdiri dari usia, income, education level, dan life style.

c. Faktor Psikologi, dengan persentasi varian sebesar $17,466 \%$ yang terdiri dari persepsi, behavior, motivasi, dan pembelajaran.

d. Faktor Sosial, dengan persentasi varian sebesar $12,204 \%$ yang terdiri dari sosial, family member, dan group factor.

e. Faktor Harga, dengan persentasi varian sebesar $6,392 \%$ yang terdiri dari price offering, resiko, dan price awareness.

Dari uraian diatas, tampak jelas bahwa nilai kumulatif varian seluruh faktor yang terbentuk mencapai 87,856\%nyang artinya tingkat keputusan wisatawan dalam membeli paket wisata di Bali Suci Tour \& Travel mencapai 87,856\%, sedangkan sisanya sebesar $12,144 \%$ adalah faktor pengaruh yang dari luar kajian yang dianalisis. Tetapi pengaruh tiap-tiap faktor terhadap keputusan wisatawan dalam membeli paket wisata berbeda-beda. Perbedaan juga terjadi dalam jumlah variabel-variabel pada tiap-tiap faktor.

6. Uji Ketepatan Model

Pada tahap ini, ketepatan model dapat diketahui dari besarnya residual yang terjadi yaitu perbedaan korelasi yang diamati dengan korelasi yang diproduksi berdasarkan hasil estimasi matriks faktor. Data yang didapat pada lampiran, dimana hasil MSA setelah mengeluarkan nilai MSA $<0,5$ menunjukan bahwa presentase residual adalah $8 \%$ dengan nilai absolute $>$ 0,005 . Hal ini mengidentifikasikan bahwa model dalam penelitian ini memiliki ketepatan sebesar $92 \%$ dengan tingkat kesalahan 5\%.
Faktor-Faktor yang Mempengaruhi Keputusan Wisatawan dalam Membeli Paket Wisata di Bali Suci Tour \& Travel

Seperti diuraikan pada enam langkah dalam analisis faktor diatas, maka faktor-faktor yang mempengaruhi keputusan wisatawan dalam membeli paket wisata di PT. Bali Suci Tour \& Travel terdiri dari 5 (lima) faktor yakni:

1. Faktor produk memiliki nilai eigenvalue yang paling besar yaitu 5,871 dan terdiri dari 4 (empat) variabel. Variabel tersebut antara lain (1) packaging, (2) guarantee, (3) perceived fit, dan (4) kualitas fasilitas. Berdasarkan analisis faktor dengan hasil faktor produk ini didukung dengan hasil observasi dan wawancara yang telah dilakukan.

Dari 11 (sebelas) informan yang diwawancarai, terdapat 6 (enam) informan yang mengatakan bahwa mereka membeli paket wisata dipengaruhi oleh produk. Beberapa diantara mereka mengatakan bahwa dengan memperhatikan kemasan paket wisata, fasilitas pendukung, itinerary perjalanan, serta jaminan kenyaman dan keamanan yang disediakan. Beberapa yang lain mengatakan bahwa paket wisata yang tersedia bersifat fleksibel (bisa request), sehingga paket wisata yang diinginkan oleh wisatawan cocok dan sesuai dengan yang wisatawan harapkan.

2. Faktor pribadi memiliki nilai eigenvalue sebesar 3,452 dan terdiri dari 4 (empat) variabel. Variabel tersebut antara lain (1) usia, (2) income, (3) education level, dan (4) life style. Berdasarkan analisis faktor dengan hasil faktor pribadi ini didukung dengan hasil observasi mengenai karakteristik wisatawan yang membeli paket wisata.

3. Faktor psikologi memiliki eigenvalue sebesar 3,144 dan terdiri dari 4 (empat) variabel. Variabel tersebut antara lain (1) persepsi, (2) behaviour, (3) motivasi, dan (4) pembelajaran. Berdasarkan analisis faktor 
dengan hasil faktor psikologi ini, didukung dengan hasil wawancara yang dilakukan, bahwa faktor yang mempengaruhi wisatawan dalam membeli paket wsiata adalah faktor psikologi. Salah satu wisatawan yang membeli paket wisata adalah wisatawan yang sudah pernah membeli paket wisata honeymoon, dan kembali lagi membeli paket wisata watersport dan adventure. Wisatawan mengatakan bahwa mereka punya pengalaman yang baik dalam segi pelayanan saat membeli paket wisata sebelumnya, sehingga merka memutuskan untuk kembali membeli paket wisata yang berbeda.

4. Faktor sosial memiliki eigenvalue sebesar 2,197 dan terdiri dari 3 (tiga) variabel. Variabel tersebut antara lain (1) sosial, (2) family member, dan (3) group factor. Berdasarkan analisis faktor dengan hasil faktor sosial ini didukung dengan hasil wawancara yang telah dilakukan. Faktor yang mempengaruhi wisatawan dalam membeli paket wisata adalah rujukan keluarga atau kerabat. Selain karena alasan rujukan, wisatawan juga mengatakan bahwa jumlah anggota keluarga atau kerabat mempengaruhi, karena semakin banyak anggota keluarga/kerabat yang ingin melakukan perjalanan wisata, maka semakin mudah untuk menentukan jenis paket wisata yang akan dibeli.

5. Faktor harga memiliki eigenvalue sebesar 1,151 dan terdir dari 3 (tiga) variabel. Variabel tersebut antara lain (1) price offering, (2) resiko, dan (3) price awareness. Berdasarkan analisis faktor dengan hasil faktor harga ini didukung dengan hasil wawancara yang telah dilakukan. Wisatawan mengatakan bahwa faktor yang mempengaruhi mereka dalam membeli paket wisata adalah karena pengaruh harga, terutama untuk wisatawan yang grup. Sebelum wisatawan memutuskan untuk membeli, mereka melakukan perbandingan harga dengan perusahaan lain.
Faktor yang Dominan Mempengaruhi Keputusan Wisatawan dalam Membeli Paket Wisata di Bali Suci Tour \& Travel

Faktor yang dominan dalam mempengaruhi keputusan pembelian dapat dilihat dari loading factor tertinggi dari keseluruhan faktor yang terbentuk. Berdasarkan hasil penelitian maka yang menjadi faktor dominan adalah faktor produk dengan loading faktor sebesar 5,871, dengan variabel packaging, guarantee, perceived fit, dan kualitas fasilitas merupakan bagian dari faktor 1 yang mempengaruhi konsumen dalam melakukan pembelian paket wisata di PT. Bali Suci Tour \& Travel. Hasil analisis faktor ini diperkuat dengan hasil observasi dan wawancara terhadap beberapa informan. Berdasarkan wawancara yang dilakukan terhadap 11 (sebelas) informan, maka diketahui bahwa 6 (enam) diantaranya mengatakan bahwa yang menjadi faktor yang mempengaruhi keputusan dalam membeli paket wisata adalah faktor produk. Sedangkan sisanya mengatakan bahwa faktor yang mempengaruhi wisatawan dalam membeli paket wisata adalah karena faktor harga, faktor keluarga/kerabat dan faktor pengalaman.

\section{SIMPULAN DAN SARAN Simpulan}

Berdasarkan hasil yang diperoleh dari analisis faktor yang digunakan, maka dapat diambil kesimpulan:

1. Faktor-faktor yang mempengaruhi keputusan wisatawan dalam membeli paket wisata di PT.Bali Suci Tour \& Travel terdiri dari:

a. Faktor produk, yang terdiri dari packaging, guarantee, perceive fit, dan kualitas fasilitas.

b. Faktor Pribadi, yang terdiri dari usia, income, education level, dan life style.

c. Faktor Psikologi yang terdiri dari persepsi, behavior, motivasi, dan pembelajaran.

d. Faktor Sosial yang terdiri dari sosial, family member, dan group factor.

e. Faktor Harga yang terdiri dari price offering, resiko, dan price awareness.

2. Faktor dominan yang mempengaruhi keputusan wisatawan dalam membeli paket wisata di PT.Bali Suci Tour \& Travel dapat 
dilihat dari nilai loading factor tertinggi, dlaam hal ini adalah faktor produk.

\section{Saran}

Adapun saran yang dapat diberikan terhadap PT.Bali Suci Tour \& Travel adalah:

1. Mengingat bahwa faktor yang paling dominan berpengaruh terhadap keputusan wisatawan dalam membeli paket wisata di PT. Bali Suci Tour \& Travel adalah faktor produk, maka disarankan agar perusahaan perlu memperhatikan dan meningkatkan inovasi dalam pengemasan paket wisata yang berkualitas, hal ini dimaksudkan agar wisatawan yang akan menggunakan semakin meningkat serta mampu mempengaruhi keputusan wisatawan dalam pembelian paket wisata.

2. Disarankan kepada PT. Bali Suci Tour \& Travel untuk memperhatikan faktor-faktor yang dapat mempengaruhi keputusan wisatawan dalam membeli paket wisata di luar dari pada faktor-faktor yang sudah terbentuk dalam penelitian ini. Misalnya faktor yang berasal dari dalam diri wisatawan seperti minat atau kegemaran, juga dari luar diri wisatawan seperti ekonomi global dan nasional, budaya, teknologi, dan politik.

\section{DAFTAR PUSTAKA}

Anonim. 1988. Surat Keputusan Direktur Jenderal Pariwisata No. Kep 16/U/II/88 Tentang Pelaksanaan Ketentuan Usaha Perjalanan.

Sugiyono, dkk. 2003. Teknik Smapling. Jakarta: Gramedia Pustaka Utama.

Yoeti, Oka A. 2003. Tour and Travel Marketing. Jakarta: Pradnya Paramita.

Yoeti, Oka A. 2008. Ekonomi Pariwisata: Introduksi, Informasi, dan Implementasi. Jakarta: Kompas. 